\title{
Cleavage Patterns of the Mycoplasma Chromosome, Obtained by Using Restriction Endonucleases, as Indicators of Genetic Relatedness Among Strains
}

\author{
SHMUEL RAZIN, $\dagger$ RYO HARASAWA, $\ddagger$ AND MICHAEL F. BARILE* \\ Mycoplasma Branch, Bureau of Biologics, Food and Drug Administration, Bethesda, Maryland 20205
}

\begin{abstract}
Purified deoxyribonucleic acids (DNAs) of representative strains of nine established serovars of the human mycoplasma Ureaplasma urealyticum and of five strains of Mycoplasma pneumoniae were digested with a variety of restriction endonucleases. The cleavage patterns obtained by electrophoresis of the digestion products separated the nine $U$. urealyticum serovars into two definite clusters, one consisting of serovars 1,3 , and 6 and the other consisting of serovars $2,4,5$, 7,8 , and 9 , in agreement with previous results obtained by electrophoresis of cell proteins and DNA-DNA hybridization. Although the five $M$. pneumoniae strains differed in virulence and adherence capacity, they exhibited similar DNA cleavage patterns, indicating a high degree of genetic homogeneity. The enzymes $K p n I$, $X h o I, B a m H I$, and $P s t \mathrm{I}$, which possess guanine-plus-cytosine-rich recognition sequences, cleaved the DNA of $U$. urealyticum (guanine-plus-cytosine content, about $28 \mathrm{mol \%}$ ) into a small number of fragments, whereas SmaI, with the recognition sequence CCC/GGG, failed to cleave $U$. urealyticum DNA into visibly distinct fragments. The same restriction enzymes produced multiband cleavage patterns with $M$. pneumoniae DNA, which has a guanine-plus-cytosine content of about $40 \mathrm{~mol} \%$. Restriction endonucleases EcoRI, HindIII, HpaI, and $X b a I$, which have recognition sequences rich in adenine plus thymine, produced multiband patterns with the DNAs of both $U$. urealyticum and $M$. pneumoniae. We concluded that the cleavage patterns of mycoplasmal DNAs digested with restriction endonucleases provide a means for determining genetic relatedness among mycoplasmas.
\end{abstract}

Classification of mycoplasmas and of procaryotes in general has been based mostly on phenotypic characteristics, including morphological, biochemical, and serological characteristics. A more direct approach to the study of genetic relatedness among mycoplasmas and other procaryotes involves analyses of deoxyribonucleic acid (DNA) base compositions and nucleotide sequences. DNA base composition analysis has been included among the tests required for definition of new mycoplasma species (10). However, DNA base composition by itself is not sufficient for determining genetic relatedness, although it may indicate unrelatedness among species and strains. The nucleotide sequence in a bacterial chromosome is the crucial factor which determines genetic relatedness. To assess nucleotide sequences in mycoplasmas, a variety of DNA-DNA hybridization tests have been used $(7,21)$.

+ Distinguished Visiting Scientist on leave from the Hebrew University-Hadassah Medical School, Jerusalem, Israel.

† Present address: Rikagaku-Kenkyusho, Hirosawa, WakoShi, Saitama 351, Japan.
The availability of restriction endonucleases, which recognize specific nucleotide sequences in DNA molecules, may provide a new approach for assessing genetic relatedness among procaryotes. The use of the EcoRI cleavage patterns of mycoplasmal DNA as a taxonomic aid was proposed by Bove and Saillard (4). However, this idea has not been developed very far, probably due to the difficulties encountered in the application of this method to the identification of Spiroplasma citri strains, many of which harbor extrachromosomal DNA of viral or plasmid origin (4). The inconsistent presence of extrachromosomal DNA in spiroplasmas (16) introduces variability in the cleavage patterns of whole-cell DNAs, hampering the use of these patterns for differentiation.

To evaluate more critically the potential contribution of restriction endonucleases to the characterization of mycoplasma genomes, we analyzed the DNAs of nine serovars of Urea plasma urealyticum and five strains of $\mathrm{Myco}$ plasma pneumoniae. The reasons why we used these organisms stem from the facts that the 
taxonomic status of $U$. urealyticum strains is still not clear (20) and that these strains apparently lack extrachromosomal DNA (Harasawa and Barile, J. Biol. Med., in press). Moreover, recent studies have provided detailed electrophoretic patterns of cell proteins $(9,13,19)$ and DNA-DNA homology data (7) for the $U$. urealyticum serovars, enabling a comparison of the results obtained by the restriction endonucleases technology with those obtained by the other methods. The $M$. pneumoniae strains were chosen for study because they differed in in vitro passage level, pathogenicity for hamsters, and ability to adsorb to cells and to inert surfaces.

\section{MATERIALS AND METHODS}

Organisms and growth conditions. Strains of serovars 1 to 8 of $U$. urealyticum were obtained from M. C. Shepard, Camp LeJeune, N.C., and a U. urealyticum serovar 9 strain was obtained from J. A. Robertson, University of Alberta, Edmonton, Canada. These organisms were grown in 1-liter batches of PPLO broth (Difco Laboratories, Detroit, Mich.) supplemented with $10 \%$ unheated horse serum, $5 \%$ fresh yeast extract (Flow Laboratories, Inc., McLean, Va.), $7 \mathrm{mM}$ urea, and 1,000 $\mathrm{U}$ of penicillin $\mathrm{G}$ per $\mathrm{ml}$. The cultures were harvested after 20 to $24 \mathrm{~h}$ of incubation at $37^{\circ} \mathrm{C}$, when the $\mathrm{pH}$ of the medium reached a value of about 7.4 (the initial $\mathrm{pH}$ was about 6.5). A pellet was obtained by centrifugation of a culture in the cold at $12,000 \times g$ for $40 \mathrm{~min}$, and each pellet was washed once with TE buffer, which contained $50 \mathrm{mM}$ tris(hydroxymethyl)aminomethane (Tris) $(\mathrm{pH} \mathrm{8.0)}$ and 10 $\mathrm{mM}$ ethylenediaminetetraacetate in water. $M$. pneumoniae strains FH (passage level, more than 300 ) and PI-1428 (passage level, 5 to 15; pathogenic for humans and hamsters) were obtained from R. M. Chanock, (National Institutes of Health, Bethesda, Md.), and $M$. pneumoniae strains MAC (passage level, more than 300), M129 (passage level, 5 to 15; pathogenic for hamsters), and B176 (avirulent and nonadherent; derived from strain M129 by multiple in vitro passages) were obtained from A. M. Collier, University of North Carolina, Chapel Hill. The organisms were grown in Roux bottles containing $70 \mathrm{ml}$ of broth (8) supplemented with $10 \%$ yeast extract and $20 \%$ horse serum (Flow Laboratories). The bottles were incubated horizontally at $37^{\circ} \mathrm{C}$ for 4 to 5 days, and the organisms which had attached to the glass were scraped off into the medium, collected by centrifugation at $10,000 \times g$ for $40 \mathrm{~min}$, and washed twice with TE buffer.

Extraction and purification of DNA. The washed cell pellet was suspended in $0.1 \mathrm{ml}$ of TE buffer, and the organisms were lysed by adding $1 \mathrm{ml}$ of $1 \%(\mathrm{wt} / \mathrm{vol})$ sodium dodecyl sulfate in TE buffer. The lysate was treated for $30 \mathrm{~min}$ at $37^{\circ} \mathrm{C}$ with preheated ribonuclease A (Worthington Diagnostics, Freehold, N.J.) at a final concentration of $50 \mathrm{\mu g} / \mathrm{ml}$ and then for $60 \mathrm{~min}$ at $37^{\circ} \mathrm{C}$ with proteinase K (Boehringer Mannheim Biochemicals, Indianapolis, Ind.) at a concentration of $100 \mu \mathrm{g} /$ $\mathrm{ml}$. The sodium dodecyl sulfate in the lysate was then precipitated by adding $100 \mu \mathrm{l}$ of $5 \mathrm{M}$ potassium acetate and incubating the preparation in ice for $30 \mathrm{~min}$. The precipitate was sedimented by centrifugation at 15,000 rpm for $10 \mathrm{~min}$ in an Eppendorf microcentrifuge. The resulting supernatant was transferred to another microcentrifuge tube and mixed with an equal volume of redistilled phenol-chloroform $(1: 1, \mathrm{vol} / \mathrm{vol})$. The aqueous phase was separated by centrifugation at 15,000 $\mathrm{rpm}$ for $15 \mathrm{~min}$ in the microcentrifuge, and the DNA was precipitated by adding 2 volumes of cold ethanol. The DNA precipitate was collected by centrifugation for $5 \mathrm{~min}$ in the microcentrifuge. The DNA pellet was dried under a vacuum and dissolved in a small volume $(25$ to $100 \mu \mathrm{l})$ of $10 \mathrm{mM}$ Tris (pH 7.5) containing $1 \mathrm{mM}$ sodium ethylenediaminetetraacetate. A sample $(5 \mu \mathrm{l})$ of the DNA solution was diluted with $0.6 \mathrm{ml}$ of phosphate-buffered saline, and the absorbance was measured at 260 and $280 \mathrm{~nm}$. The ratios of absorbance at $260 \mathrm{~nm}$ to absorbance at $280 \mathrm{~nm}$ were about 1.7 to 2.0.

Digestion with restriction endonucleases. The restriction endonucleases used were products of New England Biolabs (Beverley, Mass.). Each reaction mixture (total volume, $20 \mu \mathrm{l}$ ). contained about $5 \mu \mathrm{g}$ of mycoplasmal DNA and 50 to $60 \mathrm{U}$ of the endonuclease being tested, plus $10 \mathrm{mM}$ Tris-hydrochloride ( $\mathrm{pH} 7.5)$, $10 \mathrm{mM} \mathrm{MgSO}$, and $50 \mathrm{mM} \mathrm{NaCl}$ for digestions with BamHI, PstI, and HindIII and $50 \mathrm{mM}$ Tris-hydrochloride (pH 7.5), $10 \mathrm{mM} \mathrm{MgSO}$, and $100 \mathrm{mM} \mathrm{NaCl}$ for digestions with EcoRI, $X b a I$, and $X h o I$. For digestions with $H p a \mathrm{I}$ and $K p n \mathrm{I}$, the salt solution contained 10 $\mathrm{mM}$ Tris-hydrochloride $\left(\mathrm{pH} \mathrm{7.5)}\right.$ and $10 \mathrm{mM} \mathrm{MgSO}_{4}$, and for digestions with $\mathrm{SmaI}$ the solution contained 10 $\mathrm{mM}$ Tris-hydrochloride ( $\mathrm{pH} 7.5), 10 \mathrm{mM} \mathrm{MgSO}$, and $20 \mathrm{mM} \mathrm{KCl}$. A reaction mixture containing the endonuclease being tested, the appropriate salt solution, and $1 \mu \mathrm{g}$ of phage lambda DNA (Bethesda Research Laboratories, Gaithersburg, Md.) was used as a control for each enzyme activity. Digestions were carried out at $37^{\circ} \mathrm{C}$ for $60 \mathrm{~min}$. The reaction was stopped by adding $2 \mu \mathrm{l}$ of a tracking dye solution consisting of $0.07 \%(\mathrm{wt} / \mathrm{vol})$ bromophenol blue, $7 \%(\mathrm{wt} / \mathrm{vol})$ sodium dodecyl sulfate, and $33 \%$ ( $\mathrm{vol} / \mathrm{vol}$ ) glycerol in water.

Electrophoresis. The total volume of each reaction mixture was subjected to electrophoresis in slabs made of $1.0 \%(\mathrm{wt} / \mathrm{vol})$ agarose (type 1 ; low medium electroendomosis; Sigma Chemical Co., St. Louis, Mo.) prepared in Tris-borate buffer $(89 \mathrm{mM}$ Tris, $\mathrm{pH}$ 8.2, $2.5 \mathrm{mM}$ disodium ethylenediaminetetraacetate, 89 $\mathrm{mM}$ boric acid), which was also used as the electrophoresis buffer (12). A vertical electrophoresis apparatus (model V16; Bethesda Research Laboratories) was used at $100 \mathrm{~V}$ for about $3 \mathrm{~h}$, until the dye marker reached the bottom of the gel. The gel was stained for $15 \mathrm{~min}$ with ethidium bromide $(0.4 \mu \mathrm{g} / \mathrm{ml})$ and photographed under ultraviolet light (model C-61 ChromatoVue transilluminator; Uitra-Violet Products, San Gabriel, Calif.) by using Polaroid type $55 \mathrm{P} / \mathrm{N}$ film and a Polaroid model MP-4 land camera with an orange filter. A control preparation of undigested DNA with no restriction endonuclease from each mycoplasma was also subjected to electrophoresis to detect possible extrachromosomal DNA. Only one chromosomal band was observed, and there was no evidence of extrachromosomal bands as determined by the electrophoretic procedure used.

\section{RESULTS}

The numbers of cleavage bands revealed by agarose gel electrophoresis of $U$. urealyticum 
TABLE 1. Numbers of bands observed after agarose gel electrophoresis of $U$. urealyticum and $M$. pneumoniae DNAs cleaved by restriction endonucleases

\begin{tabular}{|c|c|c|c|c|c|c|}
\hline \multirow{3}{*}{ Enzyme } & \multirow{3}{*}{$\begin{array}{l}\text { Recognition } \\
\text { sequence }\end{array}$} & \multicolumn{3}{|c|}{ No. of bands observed } & \multicolumn{2}{|c|}{ Theoretical no. of cleavage sites ${ }^{b}$} \\
\hline & & \multicolumn{2}{|c|}{ U. urealyticum } & \multirow{2}{*}{$\begin{array}{c}\text { M. pneumoniae } \\
\text { (five strains) }^{a}\end{array}$} & & \\
\hline & & $\begin{array}{c}\text { Serovars } \\
1,3 \text {, and } 6\end{array}$ & $\begin{array}{c}\text { Serovars } \\
2,4,5,7,8, \text { and } 9\end{array}$ & & U. urealyticum & M. pneumoniae \\
\hline$\overline{S m a I}$ & $\mathrm{CCC} / \mathrm{GGG}$ & 0 & 0 & 35 & 4.3 & 44.8 \\
\hline KpnI & GGTAC/C & 0 & ca. 2 & $>50$ & 34.8 & 100.8 \\
\hline XhoI & C/TCGAG & 1 & $0-1$ & ca. 9 & 34.8 & 100.8 \\
\hline BamHI & G/GATCC & 8 & 8 & ca. 30 & 34.8 & 100.8 \\
\hline PstI & CTGCA/G & 16 & 6 & ca. 35 & 34.8 & 100.8 \\
\hline EcoRI & G/AATTC & $>50$ & $>50$ & $>50$ & 230.4 & 226.8 \\
\hline HindIII & A/AGCTT & $>50$ & $>50$ & $>50$ & 230.4 & 226.8 \\
\hline HpaI & GTT/AAC & $>50$ & $>50$ & $>50$ & 230.4 & 226.8 \\
\hline Xbal & T/CTAGA & ca. 30 & ca. 30 & ca. 35 & 230.4 & 226.8 \\
\hline
\end{tabular}

${ }^{a}$ Strains FH, MAC, B176, M129, and PI-1428.

${ }^{b}$ Calculated by the method of Nei and Li (15).

and $M$. pneumoniae DNAs digested with restriction endonucleases are shown in Table 1. Generally, the numbers of bands produced from $U$. urealyticum DNA were less with enzymes having recognition sequences rich in guanine plus cytosine $(G+C)$ than with enzymes having recognition sequences rich in adenine plus thymine. SmaI, which has a recognition sequence of CCC/GGG, was the extreme case; no visible evidence of cleavage by this enzyme was obtained with $U$. urealyticum DNA. On the other hand, the DNAs of the M: pneumoniae strains were cleaved at many sites by the enzymes with $\mathbf{G}+\mathbf{C}$-rich recognition sequences, including SmaI (Table 1).

Figures 1 through 4 show that the cleavage patterns of the nine $U$. urealyticum serovars fell into two distinct groups, one common to serovars 1,3 , and 6 and the other common to serovars $2,4,5,7,8$, and 9 . The cleavage patterns within each of these two clusters were almost identical, apart from a few cases in which a band was missing in one or more of the serovars. Thus, after digestion with $\mathrm{XhoI}$, serovars 2 and 5 differed from serovars $4,7,8$, and 9 in lacking the single cleavage band observed in the latter group of serovars (Fig. 1). The cleavage patterns obtained with PstI (Fig. 3) showed that serovar 3 lacked one of the bands found in the patterns for serovars 1 and 6 of the first cluster, whereas serovar 5 lacked one of the bands characterizing the other serovars of the second cluster. In contrast to the findings with the $U$. urealyticum serovars, the cleavage patterns of the digested DNAs of the five $M$. pneumoniae strains were almost identical, although we did observe a lack of one or two bands with some of the restriction enzymes in some of the strains (Fig. 5 and 6).

The reproducibility of the cleavage patterns was demonstrated by the identical patterns ob- tained when we tested different DNA preparations from the same strain and changed the batch of the specific restriction endonuclease used. The high reproducibility of our results can also be taken to indicate that under the experimental conditions used by us, digestion of mycoplasmal DNAs as well as digestion of lambda phage DNA, reached completion.

\section{DISCUSSION}

The cleavage patterns produced by electrophoresis of the digestion products of mycoplasmal DNAs obtained by digestion with various restriction endonucleases provide valuable information concerning the type and number of specific nucleotide sequences in the mycoplasma chromosome. The restriction endonucleases which we used recognize specific six-nucleotide sequences. The molecular weight of the $U$. urealyticum genome is $440 \times 10^{6}$ to $470 \times 10^{6}$, and that of the $M$. pneumoniae genome is about $480 \times 10^{6}$. The $\mathrm{G}+\mathrm{C}$ content of $U$. urealyticum DNA is 27.7 to $28.5 \mathrm{~mol} \%$, whereas that of $M$. pneumoniae DNA is about $40 \mathrm{~mol} \%(1-3)$. Using the formula of Nei and $\mathrm{Li} \mathrm{(15),} \mathrm{which} \mathrm{takes} \mathrm{into}$ consideration the genome size and the $\mathrm{G}+\mathrm{C}$ content of the genome, as well as of the recognition site of the restriction enzyme, we arrived at the values for theoretical cleavage sites shown in Table 1 . The low number of visible bands can be explained by the fact that some fragments may migrate together as one band. Moreover, the activities of a number of restriction endonucleases are markedly influenced by the presence of methylated bases in the DNA. Although data on the methylation of $U$. urealyticum and $M$. pneumoniae DNAs are not available, the DNAs of other mycoplasmas have been found to be methylated to various degrees, depending on the species (17). 


\section{$\begin{array}{lllllllll}1 & 3 & 6 & 2 & 4 & 5 & 7 & 9 & \lambda\end{array}$}

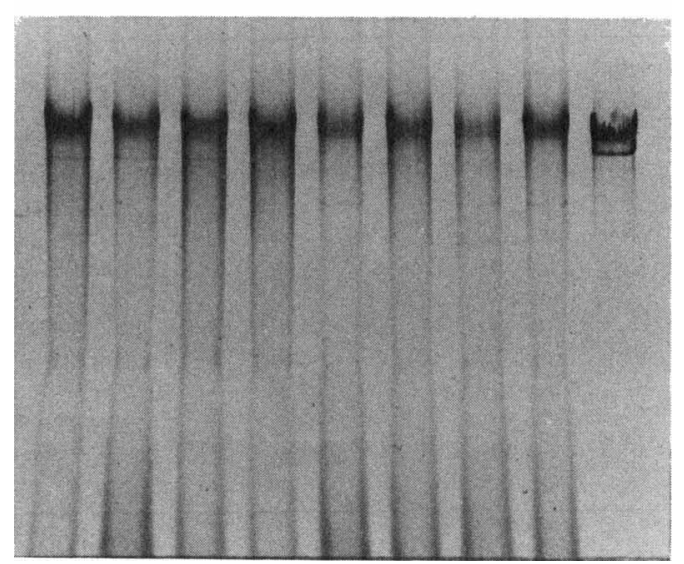

FIG. 1. Cleavage patterns of the DNAs of $U$. urealyticum serovars 1 through 7 and 9 and of phage lambda DNA digested with XhoI. A single, apparently identical cleavage fragment is present in serovars 1,3 , and 6. Serovars 4, 7,8 (not shown), and 9 contain a single cleavage fragment that migrated faster than the fragment of serovars 1,3 , and 6 . The DNAs of serovars 2 and 5 apparently were not cleaved.

Since the $\mathrm{G}+\mathrm{C}$ contents of mycoplasma DNAs are typically very low (for most species, the $\mathrm{G}+\mathrm{C}$ content varies from 23 to $30 \mathrm{~mol} \%$ [22]), restriction endonucleases with recognition sequences rich in $\mathrm{G}+\mathrm{C}$ should cut the chromosome at only a few sites producing a few fragments. On the other hand, the chromosome of $M$. pneumoniae is unique among the mycoplas-

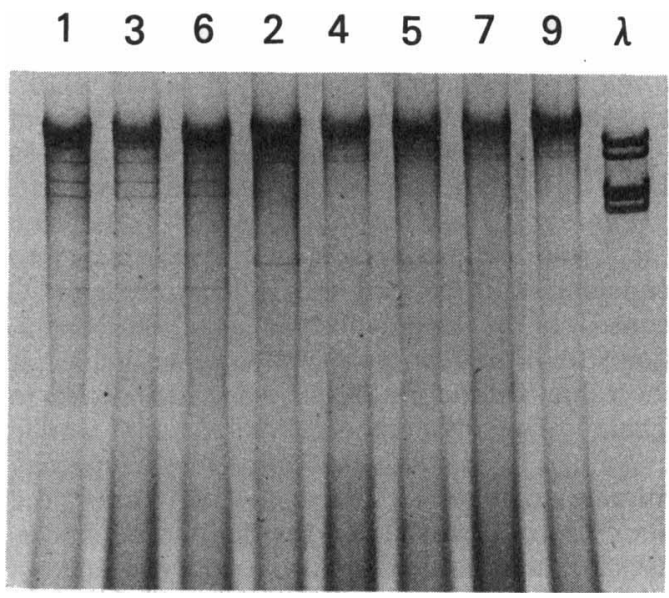

FIG. 2. Cleavage patterns of the DNAs of $U$, urealyticum serovars 1 through 7 and 9 and of phage lambda DNA digested with $B a m H I$. The cleavage patterns of serovars 1,3 , and 6 are essentially identical and different from those of serovars $2,4,5,7,8$ (not shown), and 9.

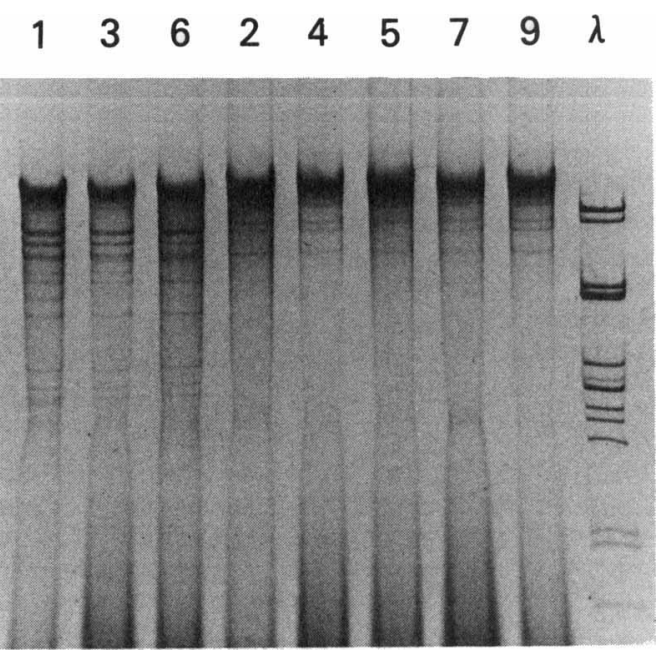

FIG. 3. Cleavage patterns of the DNAs of $U$. urealyticum serovars 1 through 7 and 9 and of phage lambda DNA digested with PstI. The cleavage pattern of serovars 1,3 , and 6 is different from that of the other serovars (including serovar 8 [not shown]). However, the patterns within each group of serovars differ in one or two bands.

mas in having a $\mathrm{G}+\mathrm{C}$ content of about $40 \mathrm{~mol} \%$. This is reflected by the much higher sensitivity of this chromosome to cleavage by restriction endonucleases having $\mathrm{G}+\mathrm{C}$-rich recognition sequences (Table 1). In fact, it is possible to utilize the DNA cleavage patterns obtained by using restriction endonucleases having $\mathrm{G}+\mathrm{C}$-rich recognition sequences as indicators of the $\mathrm{G}+\mathrm{C}$ contents of new mycoplasma isolates. Thus, our preliminary data showed that the DNA of a newly discovered human genital mycoplasma

\section{$\begin{array}{llllllllll}1 & 3 & 6 & 2 & 4 & 5 & 7 & 8 & 9 & \lambda\end{array}$}

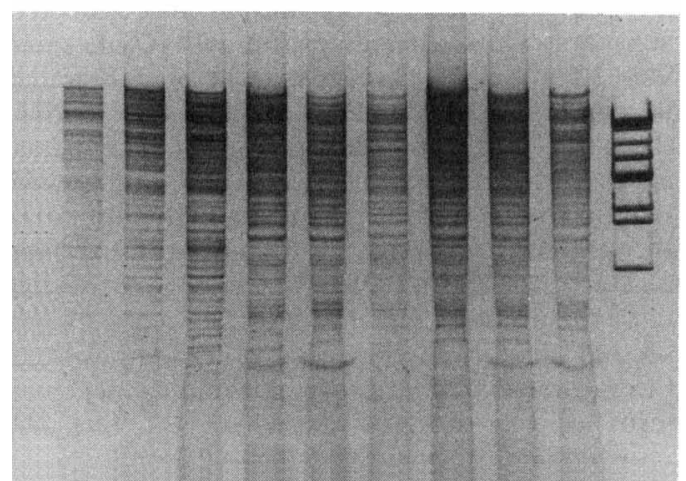

FIG. 4. Cleavage patterns of the DNAs of $U$. urealyticum serovars 1 through 9 and of phage lambda DNA digested with $\mathrm{HpaI}$. Serovars 1, 3, and 6 share a common cleavage pattern, whereas the other serovars share a different pattern. 
A

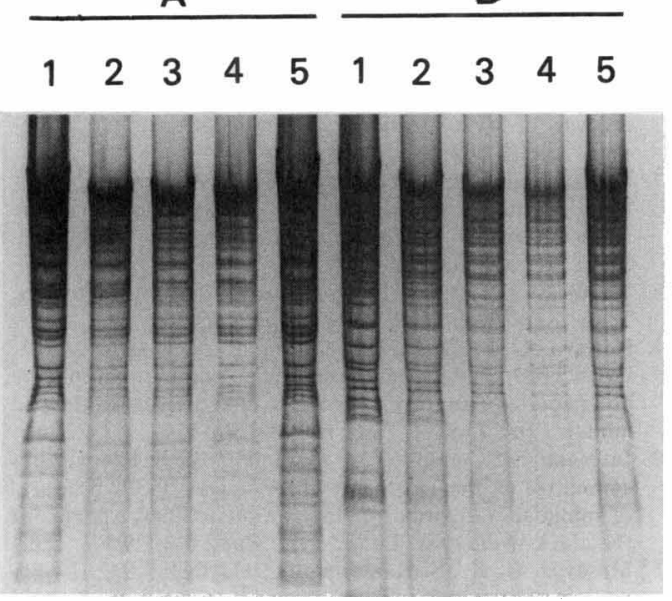

FIG. 5. Cleavage patterns of DNAs of $M$. pneumoniae strains digested with PstI (A) and SmaI (B). Lanes 1, strain FH; lanes 2, strain MAC; lanes 3, strain M129; lanes 4, strain B176; lanes 5, strain PI1428. The similarity of the patterns obtained for the five strains with each enzyme is pronounced. The arrow indicates an area with a minor difference in the pattern of bands produced by digestion with SmaI.

(23) was cut by BamHI into only a few fragments, indicating that this isolate resembles the majority of the mycoplasmas in having a low $\mathrm{G}+\mathrm{C}$ content.

Our results show that cleavage patterns, which are reproducible and characteristic for the mycoplasma strains which we tested, can serve as an effective means for determining genetic relatedness among strains. Our data illustrate this point most clearly by showing that nine serovars of $U$. urealyticum cluster in two groups, one comprised of serovars 1,3 , and 6 and the other comprised of serovars $2,4,5,7,8$, and 9. These two clusters are identical to the clusters identified by an analysis of the electrophoretic patterns of cell proteins $(9,13)$ and by DNA hybridization tests (7), lending strong support to the applicability of the restriction enzyme method for mycoplasma classification. The question of whether the two $U$. urealyticum clusters represent two different species or subspecies of the same species requires consideration of all available serological and biochemical data, in view of the still ill--Hefined species concept in procaryotes. Nevertheless, the pronounced difference between the cleavage patterns of the two chromosomes of the two clusters of serovars indicates that these groups are genetically different and therefore might represent two different species, if indeed genome structure is accepted as the basis for classification of procaryotes.

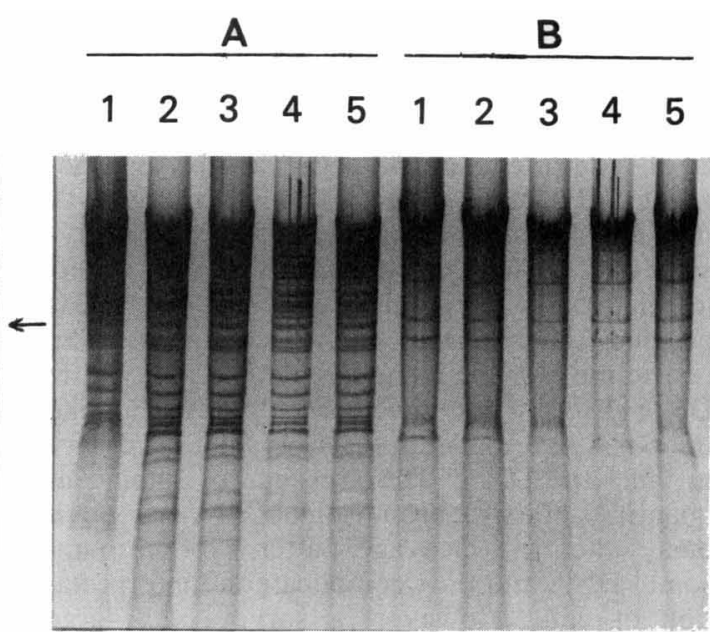

FIG. 6. Cleavage patterns of the DNAs of $M$. pneumoniae strains digested with BamHI (A) and XhoI (B). Lanes 1, strain FH; lanes 2, strain MAC; lanes 3, strain M129; lanes 4, strain B176; lanes 5, strain PI1428.

The almost identical cleavage patterns of the five $M$. pneumoniae strains obtained with all of the restriction enzymes tested demonstrate the high degree of genetic homogeneity within this species. This conclusion is also supported by the findings that the same strains are essentially indistinguishable by standard serological techniques and by one-dimensional polyacrylamide gel electrophoresis of their cell proteins (6). The $M$. pneumoniae strains used in our study were isolated in different laboratories and differed greatly in number of in vitro transfers, virulence for hamsters, and adherence ability. The possibility that the small differences observed in some of the cleavage patterns (Fig. 5) may be correlated with differences in virulence or adherence capacity is intriguing and should be investigated further.

An advantage of the restriction enzyme method compared with methods in which cell proteins are analyzed is the insensitivity of the restriction enzyme method to contamination by growth medium components. Most mycoplasmas, including $U$. urealyticum, require complex media containing serum for growth. Serum proteins usually adsorb onto the mycoplasma cell surface or precipitate and cosediment with the cells during harvesting and washing $(5,18,24)$, so that the electrophoretic patterns of mycoplasma cell proteins frequently contain bands or spots of serum proteins, which complicate the interpretation of data $(14,24)$. This problem is most pronounced with ureaplasmas. The extremely poor growth of these organisms in the media presently available (about $10^{6}$ to $10^{7}$ col- 
or-changing units per ml) yields on harvest pellets consisting mostly of precipitated medium components, including serum proteins $(11,19)$. To overcome this obstacle, it is necessary to label the proteins of the organisms by incorporating radioactive amino acids into the growth medium, a costly procedure. Cell protein analysis is only an indirect means for assessing genetic relatedness, as some genes may not be expressed under certain growth conditions. The restriction enzyme technique requires very little DNA ( 3 to $5 \mu \mathrm{g}$ is sufficient). Moreover, unlike the DNA hybridization tests, it is not necessary to label the DNA. The presence of significant quantities of extrachromosomal DNA may obviously alter the cleavage patterns of chromosomal DNA and thus complicate the interpretation of data. However, a survey of a large number of Mycoplasma species and $U$. urealyticum serovars failed to detect extrachromosomal DNA (Harasawa and Barile, in press); this was also supported by the presence of a single band of undigested DNA in our electropherograms when the endonuclease was omitted from the reaction mixture.

The use of several restriction endonucleases in an analysis of the DNA of an organism has the advantage of providing more patterns for comparison of strains. For classification purposes the enzymes which cut the DNA molecules at only a few sites have the advantage of producing cleavage patterns which are easier to compare. An enzyme like BamHI, which cuts the $U$. urealyticum chromosome at only a few sites, provides sufficient data to separate the serovars into two clusters. Nevertheless, the multiband cleavage patterns produced by EcoRI, HindIII, $X b a \mathrm{I}$, and $H p a I$, although more difficult to compare, provide more meaningful information concerning the degree of genetic relatedness among strains. In this case, identity or close similarity of cleavage patterns indicates the presence of nucleotide sequence homologies at multiple sites along the chromosome.

\section{LITERATURE CITED}

1. Bak, A. L., and F. T. Black. 1968. DNA base composition of human $T$ strain mycoplasma. Nature (London) 219:1044-1045.

2. Bak, A. L., F. T. Black, C. Christiansen, and E. A. Freundt. 1969. Genome size of mycoplasmal DNA. Nature (London) 224:1209-1210.

3. Black, F. T., C. Christiansen, and G. Askaa. 1972. Genome size and base composition of deoxyribonucleic acids from eight human T-mycoplasmas. Int. J. Syst. Bacteriol. 22:241-242.

4. Bove, J. M., and C. Saillard. 1979. Cell biology of spiroplasmas, p. 83-153. In R. F. Whitcomb and J. G. Tully (ed.), The mycoplasmas, vol. 3. Academic Press, Inc., New York.

5. Bradbury, J. M., and F. T. W. Jordan. 1972. Studies on the adsorption of certain medium proteins to Mycoplasma gallisepticum and their influence on agglutination and haemagglutination reactions. J. Hyg. 70:267-278.

6. Chandler, D. K. F., S. Razin, E. B. Stephens, R. Harasawa, and M. F. Barile. 1982. Genomic and phenotypic analysis of Mycoplasma pneumoniae strains. Infect. Immun. 38:604-609.

7. Christiansen, C., F. T. Black, and E. A. Freundt. 1981. Hybridization experiments with deoxyribonucleic acid from Ureaplasma urealyticum serovars I to VIII. Int. J. Syst. Bacteriol. 31:259-262.

8. Hayflick, L. 1965. Tissue cultures and mycoplasmas. Texas Rep. Biol. Med. 23(Suppl. 1):285-303.

9. Howard, C. J., D. H. Pocock, and R. N. Gourlay. 1981. Polyacrylamide gel electrophoresis comparison of the polypeptides from ureaplasmas isolated from cattle and humans. Int. J. Syst. Bacteriol. 31:128-130.

10. International Committee on Systematic Bacteriology, Subcommittee on the Taxonomy of Mollicutes. 1979. Proposal of minimal standards for descriptions of new species of the class Mollicutes. Int. J. Syst. Bacteriol. 29:172-180.

11. Masovar, G. K., S. Razin, and L. Hayflick. 1977. Localization of enzymes in Ureaplasma urealyticum (T-strain mycoplasma). J. Bacteriol. 130:297-302.

12. Meyers, J. A., D. Sanchez, L. P. Elwell, and S. Falkow. 1976. Simple agarose gel electrophoresis method for the identification and characterization of plasmid deoxyribonucleic acid. J. Bacteriol. 127:1529-1537. (Erratum, J. Bacteriol. 129:1171, 1977).

13. Mouches, C., D. Taylor-Robinson, L. Stipkovits, and J. M. Bove. 1981. Comparison of human and animal ureaplasmas by one and two-dimensional protein analysis on polyacrylamide slab gel. Ann. Microbiol. (Paris) 132B:171-196.

14. Mouches, C., J. C. Vignault, J. G. Tully, R. F. Whitcomb, and J. M. Bove. 1979. Characterization of spiroplasmas by one and two-dimensional protein analysis on polyacrylamide slab gels. Curr. Microbiol. 2:69-74.

15. Nei, M., and W.-H. Li. 1979. Mathematical model for studying genetic variation in terms of restriction endonucleases. Proc. Natl. Acad. Sci. U.S.A. 76:5269-5273.

16. Ranhand, J. M., W. O. Mitchell, T. J. Popkin, and R. M. Cole. 1980. Covalently closed circular deoxyribonucleic acids in spiroplasmas. J. Bacteriol. 143:1194-1199.

17. Razin, A., and S. Razin. 1980. Methylated bases in mycoplasmal DNA. Nucleic Acids Res. 8:1383-1390.

18. Rottem, S., M. Hasin, and S. Razin. 1973. Binding of proteins to mycoplasma membranes. Biochim. Biophys. Acta 298:876-886.

19. Sayed, 1. A., and G. E. Kenny. 1980. Comparison of the proteins and polypeptides of the eight serotypes of Ureaplasma urealyticum by isoelectric focusing and sodium dodecyl sulfate-polyacrylamide gel electrophoresis. Int. J. Syst. Bacteriol. 30:33-41.

20. Shepard, M. C., C. D. Lunceford, D. K. Ford, R. H. Purcell, D. Taylor-Robinson, S. Razin, and F. T. Black. 1974. Ureaplasma urealyticum gen. nov., sp. nov.: proposed nomenclature for the human $\mathrm{T}$ (T-strain) mycoplasmas. Int. J. Syst. Bacteriol. 24:160-171.

21. Stephens, E. B., G. S. Aulakh, R. E. McCoy, D. L. Rose, J. G. Tully, and M. F. Barile. 1981. Lack of genetic relatedness among animal and plant acholeplasmas by nucleic acid hybridization. Curr. Microbiol. 5:367-370.

22. Tully, J. G., and S. Razin. 1977. The mollicutes, mycoplasmas and ureaplasmas, p. 417-443. In I. Laskin and H. Lechevalier (ed.), Handbook of microbiology, 2nd ed., vol. 1. CRC Press, Boca Raton, Fla.

23. Tulley, J. G., D. Taylor-Robinson, R. M. Cole, and D. L. Rose. 1981. A newly discovered mycoplasma in the human urogenital tract. Lancet i:1288-1291.

24. Yaguzhinskaya, O. E. 1976. Detection of serum proteins in the electrophoresis patterns of total proteins of mycoplasma cells. J. Hyg. 77:189-198. 